\title{
Long-term Watershed Research in Alberta
}

he value of long-term data, as summarized by Stednick et al. (2004: p 279), is linked to watershed management needs: "Often the value of longterm [data] is not appreciated until those data are needed to respond to a management question-or, more often, a crisis." For scientists and practitioners to make informed recommendations and decisions, the impacts of land cover changes (e.g., forest harvesting, wildfire, and disease) in forested watersheds must be disentangled from inter-annual weather and climatic variability. Longterm, detailed datasets are required to predict the potential impact of future changes in climate and vegetation. The purpose of this special issue of The Forestry Chronicle is to present longterm watershed research studies (Fig. 1) that have provided useful information on regional hydrology that can then be used to make informed forest land-use and management decisions in Alberta. Although there have been many meaningful short-term studies that have advanced scientific and hydrologic knowledge, we focus on long-term watershed research (active for at least five years; Table 1) and summarize the available datasets, objectives of the research, principal results, and contact information.

The importance of long-term research sites for providing knowledge to guide watershed management are well understood in Alberta. In the 1960s, scientists in the provincial and federal governments initiated a longterm watershed research program to assess the hydrologic effects of land management in Alberta's forested headwaters (Jeffrey 1965). Experimental watersheds were instrumented in southern Alberta's Rocky Mountains with the objective of "evaluating and improving [watershed] management" by manipulating the land and forest, and observing the effects on water yield, hydrologic regime, and water quality (Jeffrey 1965: p 502). Results from these early hydrologic studies (e.g., Marmot Creek, Streeter Creek, Spring Creek, and Tri-Creeks) have provided important information on the hydrology, geo-

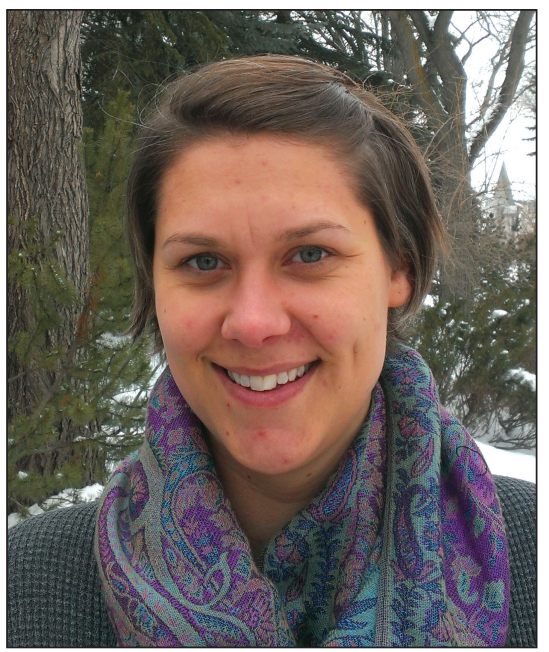

Sheena A. Spencer

fRI Research, The Water Program, Hinton and Department of Renewable Resources, University of Alberta, Edmonton

morphology, and ecology of the region. For example, results from experimental harvests in Marmot Creek indicate that it is possible to increase water yield through harvest procedures (Swanson et al. 1986). However, the optimal forest block size that maximizes water yield increases is too small given technological constraints and is not economical for commercial forest harvesting (Swanson et al. 1986). Research on suspended sediment in the Tri-Creeks Experimental Watershed showed that ensuring Best Management Practices (BMP) are being followed during harvest is critical in reducing the amount of sediment entering the stream (Jablonski 1986).

In the early 2000s, there was a renewed interest in long-term studies. New projects were initiated, including Forest Watershed \& Riparian Disturbance (FORWARD), Southern Rockies Watershed Project (SRWP), and Hydrology, Ecology and Disturbance (HEAD), which have provided valuable hydrologic knowledge to assist land managers and local officials in managing forested landscapes. The SRWP has shown that salvage logging after severe wildfire should be well-planned and approached cautiously because it can

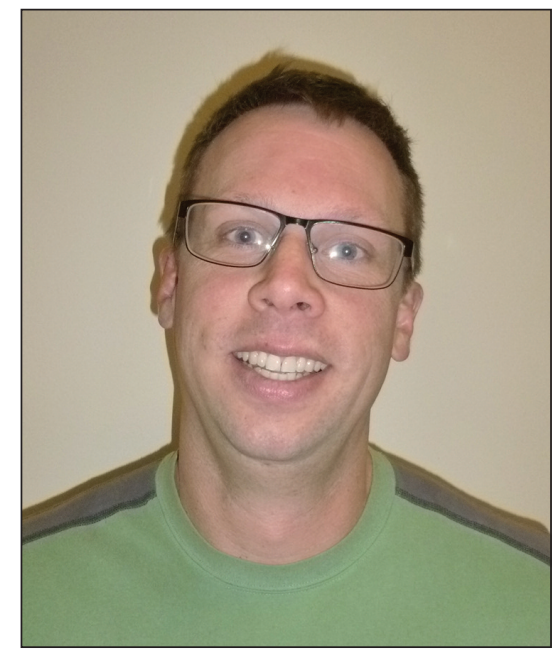

Axel Anderson

fRI Research, The Water Program, Hinton and Department of Renewable Resources, University of Alberta, Edmonton

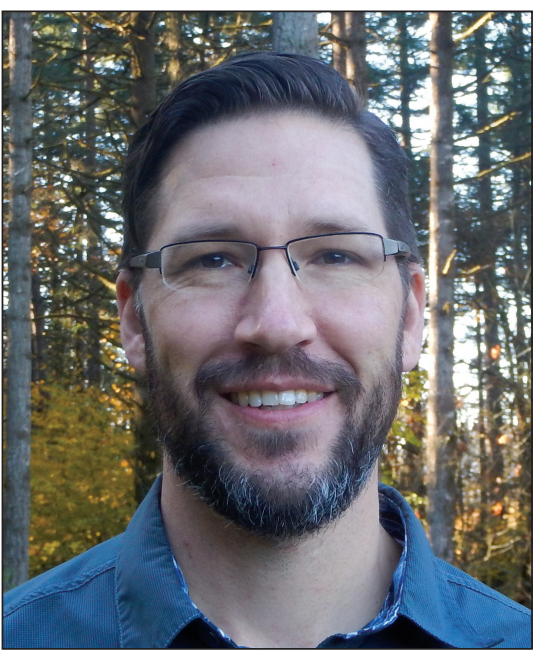

Kevin D. Bladon

Department of Forest Engineering, Resources and Management, College of Forestry, Oregon State University, Corvallis

potentially exaggerate the impacts on hydrology, water quality, and aquatic ecology more strongly than wildfire alone (Silins et al. 2016). The FORWARD project developed predictive tools for use in Millar Western's Detailed Forest Management Plan to forecast the effects of proposed forest management on streamflow and water 


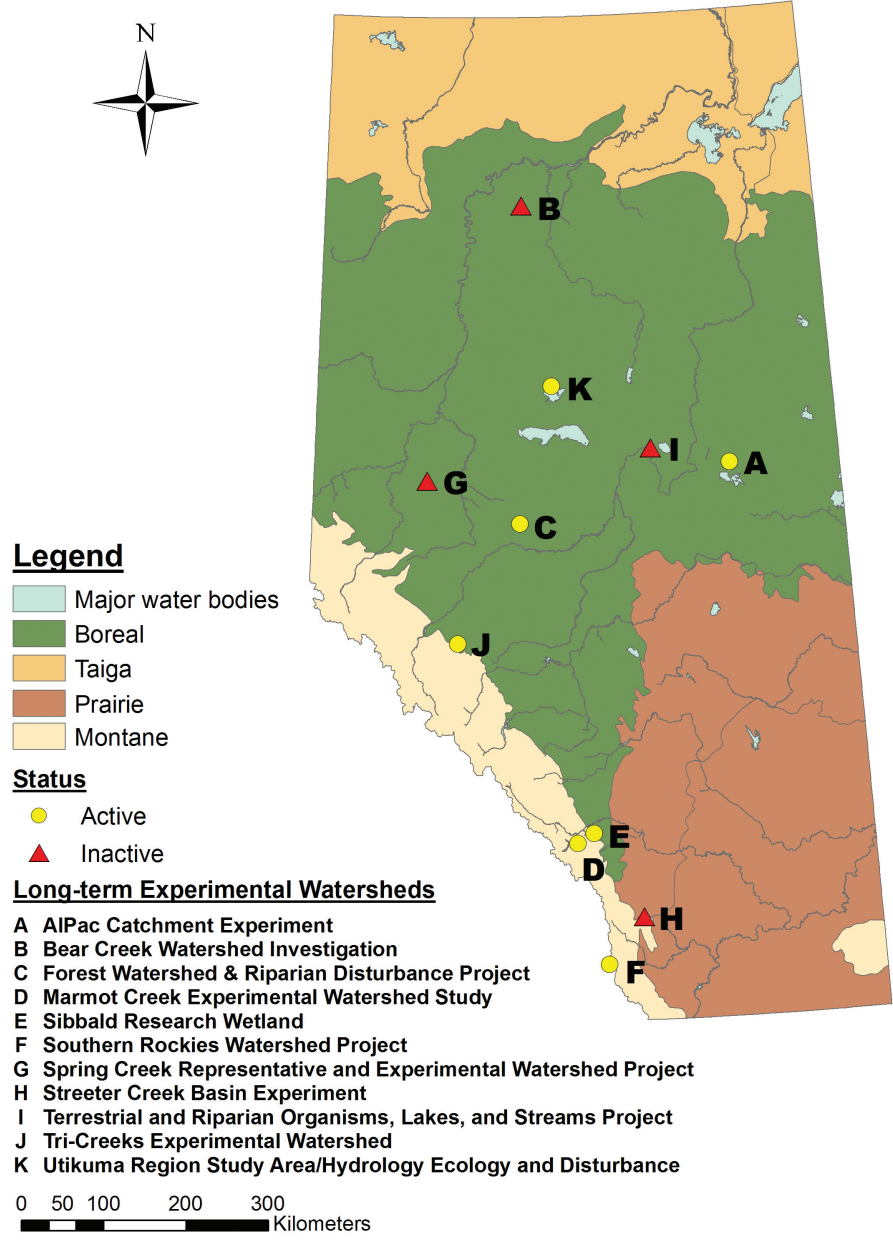

Fig. 1. Long-term watershed research sites in Alberta quality (Prepas et al. 2008). HEAD developed conceptual and predictive models that can be used in hydrological risk assessments and watershed planning to improve BMPs and road construction (Petrone et al. 2016). In addition, researchers have revisited and re-established long-term sites that were decommissioned, capitalizing on previously available data, e.g., Marmot Creek (Pomeroy 2013) and Spring Creek (Swanson and Rothwell 2001).

Other important uses of long-term watershed studies and the resulting data include:

- Provision of an educational space and outdoor laboratory where students can learn from senior scientists and scientists can learn from each other through inter-disciplinary collaborations (Rothwell 2013);

- Improved hydrologic models through better understanding of hydrology and runoff processes, which then aids in improving BMPs and policies (Prepas et al. 2008, Donnelly et al. 2016);

- Knowledge of natural disturbances and their impacts on economics and society; e.g., wildfires have the potential to significantly impact drinking water treatment, depending on the extent and severity of fire and the type of treatment infrastructure (Emelko et al. 2011);

Table 1. Long-term watershed research projects summarized in this special issue

\begin{tabular}{|c|c|c|c|}
\hline Project name & Lead agency & Duration & Current status \\
\hline AlPac Catchment Experiment (ACE) & $\begin{array}{l}\text { University of Alberta/Alberta } \\
\text { Pacific Forest Industries Inc. }\end{array}$ & 2005-present & Ongoing \\
\hline Bear Creek Watershed Investigation & Alberta Government & $1968-1973$ & Inactive \\
\hline $\begin{array}{l}\text { Forest Watershed and Riparian Disturbance } \\
\text { (FORWARD) }\end{array}$ & Lakehead University & 2001-present & Ongoing \\
\hline Marmot Creek Experimental Watershed Study & $\begin{array}{l}\text { Alberta/Canadian Government; } \\
\text { University of Saskatchewan }\end{array}$ & $\begin{array}{l}\text { 1962-1987 } \\
\text { 2005-present }\end{array}$ & Ongoing \\
\hline Sibbald Research Wetland & University of Saskatchewan & 2006-present & Ongoing \\
\hline Southern Rockies Watershed Project (SRWP) & University of Alberta & 2004-present & Ongoing \\
\hline $\begin{array}{l}\text { Spring Creek Representative and } \\
\text { Experimental Watershed }\end{array}$ & $\begin{array}{l}\text { Alberta Government/Canadian } \\
\text { Forest Service/Daishowa- } \\
\text { Marubeni International Ltd. }\end{array}$ & $\begin{array}{l}1965-1987 \\
1992-1999\end{array}$ & Inactive \\
\hline Streeter Creek Basin Experiment & Alberta/Canadian Government & $1966-1986$ & Inactive \\
\hline Terrestrial Organisms in Lakes and Streams (TROLS) & $\begin{array}{l}\text { Lakehead University/ } \\
\text { University of Alberta }\end{array}$ & 1994-2000 & Inactive \\
\hline Tri-Creeks Experimental Watershed & $\begin{array}{l}\text { Canadian Forest Service/Alberta } \\
\text { Government/University of Alberta }\end{array}$ & $\begin{array}{l}\text { 1965-1987 } \\
\text { 2015-present }\end{array}$ & Ongoing \\
\hline $\begin{array}{l}\text { Utikuma Region Study Area (URSA): Hydrology, } \\
\text { Ecology, and Disturbance of Boreal wetlands (HEAD) }\end{array}$ & University of Alberta & 1999-present & Ongoing \\
\hline
\end{tabular}


- Information for the management of natural disturbances; e.g., beaver can control peatland form, hydrologic function, and the delivery of water and nutrients downstream in wetlands. Beaver management decisions regulate the extent of beaver impact (Westbrook 2016);

- Identification of the long-term economic impacts and environmental benefits of reclaimed mined areas in the oil sands (Petrone et al. 2016);

- Baseline data for flood frequency analysis and predictions of climate change impacts; e.g., Marmot Creek data and other hydrological and meteorological data can be used to improve flood prediction and provide better management and planning tools, which may prevent some of the economic or infrastructure impacts that can occur as a result of flooding (Pomeroy 2013);

- An opportunity to study the cumulative effects of multiple land-use changes and natural disturbances (Dubé et al. 2006); and,

- Knowledge regarding the recovery of hydrology, water quality, and aquatic ecosystem health after disturbances; e.g., initial monitoring four years after the Lost Creek wildfire suggested full hydrologic and water quality recovery; however, additional monitoring (four more years) showed clearly that many water quality variables (e.g., sediment, phosphorus) remained elevated and the system had not fully recovered (Bladon et al. 2012).

For these reasons, and others, longterm sites will likely play an important role in our understanding of watershed behavior and in influencing watershed management principles. Additional examples of valuable long-term hydrologic research in Canada can be found in HELP (2008) and Redding et al. (2010).

\section{References}

Bladon, K.D., U. Silins, M. Stone, S. Boon, M.B. Emelko, C.H.S. Williams and M.J. Wagner. 2012. Incomplete recovery of water quality after wildfire in Alberta's Rocky Mountains: Insights from eight years of watershed research. Canadian Water Resources Association-Canadian Geophysical Union National Conference, Banff, AB. June 5-8, 2012.

Donnelly, M., K. Devito, C. Mendoza and R. Petrone. 2016. Long-term watershed research in Alberta: Al-Pac Catchment Experiment (ACE). Forest. Chron. (this issue).

Dubé, M., B. Johnson, G. Dunn, J. Culp, K. Cash, K. Munkittrick, I. Wong, K. Hedley, W. Booty, D. Lam, O. Resler and A. Storey. 2006. Development of a new approach to cumulative effects assessment: A northern river ecosystem example. Environ. Monit. Assess. 113: 87-115.

Emelko, M., U. Silins, K.D. Bladon and M. Stone. 2011. Implications of land disturbance on drinking water treatability in a changing climate: Demonstrating the need for "source water supply and protection" strategies. Water Res. 45(2): 461-472.

HELP. 2008. HydroEcological Landscapes and Processes (HELP). Canadian Forest Hydrology website http://www.canfor hydro.org/CFHW_AboutHelp.htm.

Jablonski, P.D. 1986. Tri-Creeks: Documentation of the timber harvesting operation from a watershed management perspective. Alta. Ener. Nat. Res., Forest Land Use Branch. In-house document.

Jeffrey, W.W. 1965. Experimental watersheds in the Rocky Mountains, Alberta, Canada. In: Symposium of Budapest, Proceedings of the Symposium on Representative and Experimental Areas, 28 Sept-5 Oct 1965, Budapest, Hungary, pp. 502-521.

Petrone, R., K. Devito and C. Mendoza. 2016. Long-term watershed research in Alberta: URSA - Aspen harvest and recovery study. Forest. Chron. (this issue).

Pomeroy, J. 2013. Learning from the floods of 2013, 2012, 2011. Calgary Herald. Accessed: Nov. 26, 2013 from: http://www. calgaryherald.com/news/Pomeroy+ Learning+from+floods $+2013+2012+2011 / 90$ 12976/story.html.
Prepas, E.E., G. Putz, D.W. Smith, J.M. Burke and J.D. MacDonald. 2008. The FORWARD Project: Objectives, framework and initial integration into a Detailed Forest Management Plan in Alberta. Forest. Chron. 84: 330-337.

Redding, T.E., R.D. Moore, R.D. Winkler, R.G. Pike and D.J. Wilford. 2010. Longterm watershed research in British Columbia. Streamline Watershed Management Bulletin 14: 1-35.

Rothwell, R. 2013. Short history of Marmot Creek Experimental Watershed: People, places and things done. Marmot Creek Research Basin Workshop, Kananaskis Country, Alberta.

Silins, U., A. Anderson, K.D. Bladon, M.B. Emelko, M. Stone, S.A. Spencer, C.H.S. Williams, M.J. Wagner, A.M. Martens and K. Hawthorn. 2016. Long-term watershed research in Alberta: Southern Rockies Watershed Project. Forest. Chron. (this issue). Stednick, J.D., C.A. Troendle and G.G. Ice. 2004. Lessons for watershed research in the future. In A century of forest and wildland watershed lessons. G.G. Ice and J.D. Stednick (eds.). Society of American Foresters, Bethesda, Md. pp. 277-287.

Swanson, R.H., D.L. Golding, R.L. Rothwell and P.Y. Bernier. 1986. Hydrologic effects of clear-cutting at Marmot Creek and Streeter Watersheds, Alberta. Information Report NOR-X0278. Northern Forestry Centre, Canadian Forestry Service. 27 p.

Swanson, R.H. and R.L. Rothwell. 2001. Hydrologic recovery of Aspen clearcuts in Northwestern Alberta. In Shepperd, W.D., D. Binkley, D.L. Bartos, T.J. Stohlgren, L.G. Eskew, comps. Sustaining aspen in western landscapes: Symposium proceedings. 13-15 June 2000. Grand Junction, CO. Proceedings RMRS-P-18. Fort Collins, CO., U.S. Department of Agriculture, Forest Service, Rocky Mountain Research Station. pp 121-136.

Westbrook, C. and A. Bedard-Haughn. 2016. Long-term watershed research in Alberta: Sibbald Research Wetland: Mountain peatland form and ecohydrologic function as influenced by beaver. Forest. Chron. (this issue). 